\title{
Physicochemical properties of hydrolyzed collagen produced from chicken feet
}

\author{
Mahmoud F.S.A. Kodous
}

\begin{abstract}
Meat \& Fish Technol. Res. Dept., Food Technology Research Institute, Agricultural Research Center,
\end{abstract} Giza, Egypt.

Received: 17 Nov. 2019 / Accepted 16 Jan. 2020 / Publication date: 25 Jan. 2020

\begin{abstract}
Chicken feet can be used as an substitution source for production hydrolyzed collagen as new desirable healthy food product, this study aims to use the enzymatic hydrolysis method for chicken feet (considered as byproduct) to produce hydrolyzed collagen with orange flavor to be food supplement for anti-aging, anti- osteoporotic and anti arthritis, anti-inflammatory, anti tumor. The results indicated that the hydrolyzed collagen that produced in this study was high in all enzymatic treatments(enzyme concentrate $0.03,0.04$ and $0.05 \%$ ) of glycine, proline and hydroxyproline content, as known that proline and hydroxyproline percent were very important for producing glucosamine in the human body in the presence of ascorbic acid. The results showed that adding orange essence, as well as ascorbic acid during producing of hydrolyzed collagen increased the nutritional value especially in vitamin $C$ from $0 \mathrm{mg} / 100 \mathrm{~g}$ of hydrolyzed collagen without any additives (G1) to 500 $\mathrm{mg} / 100 \mathrm{~g}$ in hydrolyzed collagen with orange essence, as well as ascorbic acid (G2). While protein content decreased from $91.38 \%$ to $90.58 \%$. For sensory evaluation it was found that color, odor, taste, texture and overall acceptability for hydrolyzed collagen with orange essence, as well as ascorbic acid (G2) was higher than hydrolyzed collagen (G1).
\end{abstract}

Keywords: Chicken feet, Hydrolyzed collagen, Utilization of By-product, New product of chicken feet.

\section{Introduction}

The new food products detect through developing studies and the find of new sources of food or the reuse of by-products or wastes. Therefore, nutritional and sensory aspects must be taken into account, so they could equipping some vitamins or minerals without refusal the product by the consumers. In this context, there are the so-called functional foods (Barcelos et al., 2002; Barimalaa and Okoroji, 2009 and Rodrigues et al., 2011). Laufenberg et al. (2003) and Costa et al. (2008), who find that the meat waste may contains many substances with high values which If employing an appropriate technology, this material probably converted into commercial products or raw materials to secondary processes. In this context, can be several food wastes which previously as useless currently are transformed into by-products with wide commercial acceptance. Whereas, to take advantage of the waste is convert to a new products this providing a better destiny with higher commercial value to them. it is necessary to search for alternative foods to meet demand because of the world population increasing, on condition these alternative sources should have nutritive food produced at large scale with low cost, and also should present good sensory characteristics. Orrico Junior et al. (2010a and $2010 \mathrm{~b}$ ) found that the poultry manufacturing producing a large amounts of waste that if well managed could become an important source of income and add value to the activity, also a sustainable production model that is increasingly becoming a requirement of the market. Therefore, a system of waste treatment became necessary in order to avoid possible contamination of the environment. Polian, (2012) reported that by-products of the slaughtering and processing of chickens include viscera, head, feet, skin, fat, bone. Also chicken feet comprise of protein $22.46 \%$, and collagen is the major component of protein .Food and pharmaceutical industries throughout the world are watching a growing demand for collagen and gelatin. The collagen protein substance is naturally occurring in the human body, but the problem occurs with age progress, the body's ability to produce less collagen, which leads to changes in flexibility and increase in the inflammatory pain and arthritis so it is recommended to take collagen from another source. The gelatin of mammals (pigs and cattle) is the

Corresponding Author: Mahmoud F.S.A. Kodous, Meat \& Fish Technol. Res. Dept., Food Technology Research Institute, Agricultural Research Center, Giza, Egypt.

E-mail: mahmoudkadous@yahoo.com 
most popular and using, but observing many skepticism among consumers because of socio-cultural and health concerns (Karim and Bhat, 2009). The demand for new gelatin as alternative the gelatin of mammals has guided several studies on different raw materials. Collagen is formed mainly from connective tissue of animals. It has a specific secondary structure known as triple helix, which confers strength to the connective tissue matrix. This includes all the myofibril cells allowing coordinated action of movement (Hernandez-Briones et al., 2009).

Collagen extracted from collagen-rich materials with hot water is known as gelatin. The further enzymatic hydrolysis of gelatin results in collagen hydrolysate $(\mathrm{CH})$. Collagen hydrolysate used from long been in pharmaceuticals and foods in many countries and regions, such as United States, Europe, China and Japan. Approved as Generally Recognized As Safe (GRAS), the safety of $\mathrm{CH}$ has been confirmed by the Food and Drug Administration (FDA) Center for Food Safety and Nutrition. also there are many studiedes have been widely on the bioavailability and absorption of $\mathrm{CH}$ and reported that $\mathrm{CH}$ is more easily absorbed and best of bioavailability compared with gelatin (Oesser et al., 1999 and Song et al., 2017). In addition to free amino acids, small peptides especially dipeptide and tripeptide are absorbed into body by peptide transporter (Brandsch, 2013). To date, about 30 peptides (mainly dipeptides and tripeptides) have been identified in blood after ingestion of gelatin and $\mathrm{CH}$, and Pro-Hyp is the most numerous collagen-derived peptide (Wang et al., 2015 and Yazaki et al., 2017). Ohara et al. (2010) and Hatanaka et al. (2014) who reported that these peptides may do various beneficial effects on body health as in prior studies, therefor Collagen hydrolysate $(\mathrm{CH})$ has received increasing attention in recent decades, because of the recent developments regarding the beneficial effects of $\mathrm{CH}$ in animal experiments and clinical trials. These beneficial effects include anti-oxidant, anti-aging, anti- osteoporotic and anti osteoarthritis, anti-inflammatory, anti tumor, wound healing, anti- hypertensive and anti-atherosclerotic, anti-obesity and hypoglycemic effects (Hongdong and Bo, 2017).

There are many methods for collagen extraction, but the most used consider the acid and enzymatic hydrolysis methods, may increase enzyme activity at low $\mathrm{pH}$ and temperature close to the human body (Simões et al., 2014; Lin \& Liu, 2006). In chicken feet there are different studies of extraction of collagen, either by cooking (Alves \& Prudencio-Ferreira, 2002) or enzymatic methods (Hashim et al., 2014).

The aim of this investigation production hydrolyzed collagen by enzymatic hydrolysis method for chicken feet to take advantage of the nutritional value and the benefits of the healthy ingredients in the production of desirable food product as hydrolyzed collagen, with study the chemical composition, the physical and chemical quality attributes and the sensory evaluation of hydrolyzed collagen product.

\section{Materials and Methods}

\section{Raw materials.}

Chicken feet were obtained from the local market at Giza, Egypt. Immediately after slaughtering, the samples were transported using an ice box to the laboratory of Meat and Fish Technology, Food Technology Research Institute. Protease (pro type 2, 3×106/gm.) enzyme was purchasing from infoenzyme Germany. Orange essence powder was purchasing from El zawawy Company, Ataba, Cairo, Egypt. Ascorbic acid was purchasing from El-Gomhouria Co. for Trading pharmaceutical, Chemicals and Medical Equipments, Cairo, Egypt.

\section{Pretreatment.}

A previously described pretreatment procedure was applied with some modifications (Yang et al., 2009 and Wei et al., 2013). First, the chicken feet were washed, the nails and the thin yellow layer removed and washed again with cold water and cut into small pieces. The chicken feet immersed in $0.25 \mathrm{~mol} / 1 \mathrm{NaOH}$ and $1 \%(\mathrm{v} / \mathrm{v})$ hydrogen peroxide $(1: 7, \mathrm{w} / \mathrm{v})$ and held at room temperature for 40 minutes. The chicken feet samples were drained, which was squeezed by hand. The alkali pretreated chicken feet samples were then washed under running tap water for $40 \mathrm{~min}$ and drained, and subsequently soaked in $0.2 \%$ sulphuric acid $(1: 7, \mathrm{w} / \mathrm{v})$ for 40 minutes. The liquid was drained and the samples were flushed with tap water. Finally, the chicken feet samples were soaked in $0.3 \mathrm{~mol} / 1$ acetic 
acid $(1: 7, \mathrm{w} / \mathrm{v})$ for $40 \mathrm{~min}$ and flushed with tap water to remove the remaining acid. The chicken feet samples were then drained and weighed.

\section{Enzymatic hydrolysis of chicken feet.}

Enzymatic hydrolysis of chicken feet was performed using $0.03,0.04$ and $0.05 \%(\mathrm{w} / \mathrm{w})$ protease at $45^{\circ} \mathrm{C}$ for $6 \mathrm{~h}$. At the end of the hydrolysis, the enzyme was inactivated by heating at $100^{\circ} \mathrm{C}$ for 10 minutes.

\section{Filtration and lyophilisation.}

The extract was filtered through a metal sieve (100 mesh) to remove any residues. Then fine residues were removed by centrifugation at $3000 \mathrm{rpm}$ for $30 \mathrm{~min}$ at $4{ }^{\circ} \mathrm{C}$. The resulting solution was adjusted to $\mathrm{pH} 7$ with $0.1 \mathrm{~N}$ of $\mathrm{NaOH}$ or $\mathrm{HCl}$. Finally. The solution was then freeze-dried in a lyophiliser. The freeze-dried product was stored at $-20^{\circ} \mathrm{C}$ until use.

The freeze-dried collagen hydrolyzed sample (only of produced by $0.05 \%$ enzyme concentration because it were the highest of yield and protein content compared with concentrate 0.04 and $0.03 \%$ as in table 2) was divided to two groups, the first one group (G1) still without any additives and the second group (G2) was made by addition of orange essence powder $(3 \mathrm{~g} / 1000 \mathrm{~g})$, as well as ascorbic acid $(5 \mathrm{~g} / 1000 \mathrm{~g})$ to the sample.

The yield (\%) was calculated as (freeze-dried hydrolysates $(\mathrm{g}) /$ wet chicken feet $(\mathrm{g})) \times 100$.

\section{Chemical analysis.}

Chemical analysis proximate analysis including moisture, protein, fat and ash was carried out according to the methods of (AOAC, 2005), Amino acids were determined according to Milliporo Cooperative (1987). pH value was determined according to Aitken et al. (1962). Isoelectric point was determined according to Gabriela et al. (2018).

\section{Physical quality attributes}

\section{Viscosity}

The viscosity of the liquid was measured according to Brookfield Manual (1998).

\section{Turbidity}

The turbidity of the liquid was determined by measuring the absorbance (A) at $900 \mathrm{~nm}$ in $1 \mathrm{~cm}$ cuvette cells against Milli-Q water (Bses, 2001a).

\section{Solubility}

The solubility of hydrolyzed collagen powder was determined using the procedure developed by (Eastman and Moore, 1984) as adopted by Cano-Chauca et al., (2005). One gram of the powder (dry weight basis) was dispersed in $100 \mathrm{~mL}$ distilled water by blending at high speed for $5 \mathrm{~min}$. The dispersed powder was then centrifuged at $5000 \mathrm{rpm}$ for $5 \mathrm{~min} .25 \mathrm{~mL}$ aliquot of the supernatant was carefully pipetted and transferred to a pre-weighed aluminum dish and then oven-dried at $105^{\circ} \mathrm{C}$ for 3 $\mathrm{h}$. Drying was continued and weighed every hour for $2 \mathrm{~h}$. The solubility of the powder (\%) was determined by taking the weight difference.

\section{Bulk density}

The bulk density of the powder samples was measured by the procedure described in previous studies with some modification (Barbosa-Canovas et al., 2005 and Goula and Adamopoulus, 2008). Approximately $5 \mathrm{~g}$ of powder was freely poured into a $25 \mathrm{~mL}$ glass graduated cylinder (readable at 1 $\mathrm{mL}$ ) and the samples were repeatedly tapped manually by lifting and dropping the cylinder under its own weight at a vertical distance of $14 \pm 2 \mathrm{~mm}$ high until negligible difference in volume between succeeding measurements was observed. Given the mass (m) and the apparent (tapped) volume of the powder, the powder bulk density was computed as $\mathrm{m} / \mathrm{v}\left(\mathrm{kg} / \mathrm{m}^{3}\right)$. The measurements were carried out at room temperature in three replicates for all samples. 


\section{Sensory evaluation}

Sensory evaluation was determined according to Suderman et al. (1981). Immediately after preparing of samples, samples were prepared by soluting $10 \mathrm{gm}$ of powder in $100 \mathrm{ml}$ water and subjected to member's trained sensory panel to find out the samples that have more palatability by evaluating color, odor, taste, texture and overall acceptability of these samples.

\section{Statistical analysis.}

The obtained data were exposed to analysis of variance followed by multiple comparisons between means $(\mathrm{P} \leq 0.05)$ applying LSD. The analysis was carried out using the PRO ANOVA procedure of Statistical Analysis System (SAS, 1996).

\section{Results and Discussion}

Table (1) showed that the chemical composition of chicken feet, where protein, fat and ash content recorded 79.39,17.35 and 3.26\%.The protein content was like protein content, but the ash content was lower than ash content that obtained by Hashim et al. (2014), It was known that $72.5 \%$ of the protein of the chicken foot in the form of collagen. Collagen is considered to be one of the most useful biomaterials because it has a wide range of industrial applications (Lafarga and Hayes, 2014). The demand in the food industry for collagen and gelatin increasing because of their high protein content and their functional properties.

Table 1: Chemical composition of chicken feet (on dry weight basis)

\begin{tabular}{cc}
\hline Content & \% \\
\hline Protein & 79.39 \\
Fat & 17.35 \\
Ash & 3.26 \\
\hline
\end{tabular}

The results in table (2) showed that there are significant differences between the yield and Protein content of used different concentrations, where the yield and protein contents were the highest in samples of collagen hydrolyzed (concentrate $0.05 \%$ ) compared with concentrate 0.04 and $0.03 \%$,respectively. This may be due to the concentration of enzyme protease which influenced positively on the hydrolyzation degree, where the treatments with the highest concentration of the enzyme $(0.05 \%)$ has the highest of the yield and protein content. According to Simões et al. (2014) and Arauja et al. 2018), may be protease enzyme digested the protein's cross-linking sites for the triple helix structure which led to increase the yield and Protein content. Therefore, higher amounts of protease enzyme imply a higher of the yield and Protein content. At the same table (2), the data showed that samples of collagen hydrolyzed (concentrate $0.05 \%$ ) recorded the highest value of $\mathrm{pH}$ followed by samples (concentrate 0.04 and $0.03 \% \%$, respectively). This is confirmed by the higher protein content of samples of collagen hydrolyzed ( concentrate $0.05 \%$ ) than samples (concentrate 0.04 and $0.03 \%$ ) as there is direct relationship between protein content and $\mathrm{pH}$ value (SanchezAlonso et al., 2007).

Table 2: Physicochemical properties of collagen hydrolyzed at different concentration of protease enzyme.

\begin{tabular}{|c|c|c|c|c|}
\hline \multirow{2}{*}{ Item } & \multicolumn{3}{|c|}{ Concentration of protease enzyme (\%) } & \multirow[t]{2}{*}{ L SD } \\
\hline & 0.03 & 0.04 & 0.05 & \\
\hline Yield (\%) & $11.0^{\mathrm{b}} \pm 0.7$ & $13.0^{\mathrm{a}} \pm 0.75$ & $14.0^{\mathrm{a}} \pm 0.65$ & 1.401 \\
\hline Protein content (\%) & $90.34^{c} \pm 0.3$ & $90.75^{\mathrm{b}} \pm 0.2$ & $91.38^{\mathrm{a}} \pm 0.15$ & 0.350 \\
\hline pH & $5.3^{c} \pm 0.5$ & $5.45^{\mathrm{b}} \pm 0.5$ & $5.80^{\mathrm{a}} \pm 0.5$ & 0.099 \\
\hline Isoelectric point & $4.43^{\mathrm{a}} \pm 0.01$ & $4.40^{\mathrm{a}} \pm 0.05$ & $4.37^{\mathrm{a}} \pm 0.04$ & 0.075 \\
\hline Solubility & $75.12^{\mathrm{a}} \pm 0.6$ & $75.45^{\mathrm{a}} \pm 0.35$ & $75.78^{\mathrm{a}} \pm 0.25$ & 0.8515 \\
\hline
\end{tabular}

The values in same a row followed by the same letter are not-significantly different $(\mathrm{P} \leq 0.05)$.

Isoelectric point that is defined as that $\mathrm{pH}$ value at which the global electrical charge of the molecule is null,an important parameter of proteins because each protein has different isoelectric point has a specific behavior of solubility, chemical reactivity, viscosity, osmotic pressure and 
hydration of the minimum colloidal particles (Gabriela et al., 2018). Samples of collagen hydrolysate from used different concentrations (concentrate $0.05,0.04$ and $0.03 \%$ ) recorded Isoelectric point values as next $4.37,4.4 .40$ and 4.43 , respectively. which is inversely proportional with hydrolysis degree and concentrations of enzyme, this may be due to the higher density of carboxyl groups resulted by the hydrolysis of side amide groups of samples under private conditions of the strong base and high temperature (Yang et al., 2009).

From the data presented in table (3), found that the hydrolyzed collagen that produced in this study was high in glycine, the proline and hydroxyproline content in all treatments. This results agreement with the results by Masoud, (2017), as known that Proline and Hydroxyproline percent were very important for producing glucosamine in the human body in the presence of ascorbic acid (Morimura et al., 2002). On the other hand, the results noticed that values of hydroxyproline, proline and glycine content increased with increasing of the concentration of protease enzyme. Where content of hydroxyproline, proline and glycine were the highest in samples (concentrate $0.05 \%$ ) compared with concentrate 0.04 and $0.03 \%$, respectively. This may be due to the protease concentrate which influenced positively on the hydrolyzation degree, where the treatment with the highest concentration of the enzyme $(0.05 \%)$ has the highest of this amino acids contents. According to Simões et al., (2014) and Arauja et al., (2018), may be the protease enzyme digestion the protein's cross-linking sites for the triple helix structure which led to increased content of glycine content, the proline and hydroxyproline. Therefore, higher amounts of protease enzyme imply a higher content of hydroxyproline, proline and glycine amino acids.

Table 3: Amino acids of collagen hydrolyzed at different concentration of protease enzyme.

\begin{tabular}{lccc}
\hline Amino acids mg/100g & \multicolumn{3}{c}{ Hydrolyzed collagen } \\
\hline Hydroxyproline & $\mathbf{0 . 0 3}$ & $\mathbf{0 . 0 4}$ & $\mathbf{0 . 0 5}$ \\
Aspartic & 83.9 & 88.8 & 94.7 \\
Therionine & 42.2 & 31.8 & 25.6 \\
Serine & 48.9 & 42.02 & 30.6 \\
Glutamic & 33.2 & 34.1 & 36.1 \\
Glycine & 85.3 & 82.6 & 70.9 \\
Alanine & 330.2 & 345.5 & 360.6 \\
Valine & 131.18 & 124.13 & 117.29 \\
Isoleucine & 20.1 & 21.06 & 25.1 \\
Leucine & 8.3 & 7.3 & 6.8 \\
Tyrosine & 20.4 & 16.9 & 13.5 \\
Phenyl alanine & 1.02 & 0.89 & 0.81 \\
Histidine & 11.3 & 10.5 & 8.7 \\
Lysine & 9.1 & 8.9 & 7.7 \\
Arginine & 30.1 & 32.05 & 35.4 \\
Proline & 5.6 & 5.7 & 5.9 \\
Hydroxylysine & 120.3 & 128.5 & 140.3 \\
Methionine & 6.6 & 6.65 & 7.1 \\
& 12.3 & 12.6 & 12.9 \\
\hline
\end{tabular}

From the results presented in table (4) showed that significant differences between G1 and G2 in protein content, while non- significant differences between G1 and G2 in the moisture and ash .On other hand $\mathrm{pH}$ value decreased from 5.3 in $\mathrm{G} 1$ to $4.2 \%$ in $(\mathrm{G} 2)$. This may be due to adding orange essence powder, as well as ascorbic acid during producing hydrolyzed collagen. From the same table it could be observed that adding ascorbic acid during producing of hydrolyzed collagen caused to increase the nutritional value of collagen especially in vitamin $C$ from $0 \mathrm{mg} / 100 \mathrm{~g}$. to 500 $\mathrm{mg} / 100 \mathrm{~g}$ which is very important to forming glucosamine by reaction with collagen amino acid especially proline and hydroxyproline in the human body (Kramer et al., 1999). This results confirmed with the results obtained by Masoud, (2017) |who founded that moisture content increased from 2.0 in the hydrolyzed collagen to $2.87 \%$ in the hydrolyzed collagen added to it orange juice concentrate, while the protein content was decreased from 91 to $88 \%$. For $\mathrm{pH}$ it found that by adding orange juice concentrate decrease the $\mathrm{pH}$ from 6.5 to be 4.3 due to the acid content of concentrated orange juice 
Table 4: Chemical composition of hydrolyzed collagen (G1 and (G2).

\begin{tabular}{cccc}
\hline Parameters & \multicolumn{2}{c}{ hydrolyzed collagen } & \multirow{2}{*}{ LSD } \\
\cline { 2 - 3 } on dry weight bass & G1 & G2 & 0.8149 \\
\hline Moisture & $3.78^{\mathrm{a}} \pm 0.3$ & $4.41^{\mathrm{a}} \pm 0.33$ & 0.4013 \\
Protein & $91.38^{\mathrm{a}} \pm 0.5$ & $90.86^{\mathrm{b}} \pm 0.4$ & 0.6231 \\
Ash & $4.84^{\mathrm{a}} \pm 0.25$ & $4.73^{\mathrm{a}} \pm 0.56$ & 0.2266 \\
pH & $5.30^{\mathrm{a}} \pm 0.1$ & $4.2^{\mathrm{b}} \pm 0.1$ & - \\
Vitamin C & - & $500 \mathrm{mg}$ & \\
\hline
\end{tabular}

The values in same a row followed by the same letter are not-significantly different $(\mathrm{P} \leq 0.05)$.

G1) $=$ Powder of the freeze-dried collagen sample without any additives.

$\mathrm{G} 2=$ Powder of the freeze-dried collagen added to it orange essence powder, as well as ascorbic acid.

From the table (5), it could be observed that viscosity increased from 5.14 in collagen sample without any additives (G1) to 5.85 in collagen sample with orange essence powder, as well as ascorbic acid (G2). The color of collagen sample without any additives (G1) is changed from creamy color to yellow color also the flavor become orange flavor and the turbidity was increased from 11.3 in (G1) to be 17.6 nut in (G2), also bulk density increased from 0.45 in (G1) to 0.51 (G2). This may be due to adding orange essence powder. This results confirmed with the results obtained by Masoud, (2017). Who reported that the color of the hydrolyzed collagen changed from creamy color to yellow color also the flavor become orange flavor duo to adding orange juice and turbidity was increase from 10 in control to be 18 in produced collagen with orange juice concentrate and this was due to the acid content of concentrated orange juice

Table 5: Physical properties of hydrolyzed collagen and hydrolyzed made with added orange essence powder, as well as ascorbic acid.

\begin{tabular}{cccc}
\hline Parameters & Units & \multicolumn{2}{c}{ Hydrolyzed collagen } \\
& G1 & G2 \\
\hline Viscosity & mpa.s & 5.14 & 5.85 \\
Turbidity & NUT & 11.3 & 17.6 \\
Flavor & & Gelatin & Orange \\
Color & & Creamy & Yellow \\
Bulk Density & $\mathrm{g} / 1$ & 0.45 & 0.51 \\
\hline
\end{tabular}

G1 $=$ Powder of the freeze-dried collagen sample without any additives.

$\mathrm{G} 2=$ powder of the freeze-dried collagen added to it orange essence powder, as well as ascorbic acid.

Table (6) shows the mean values obtained from the sensory evaluation of the freeze-dried collagen sample without any additives (G1) and the freeze-dried collagen added to orange essence powder, as well as ascorbic acid (G2). According to the obtained results was observed significant differences between samples for odor, taste, color, texture and overall acceptability. This may be due to the orange essence led to enhance the sensory attributes of the final products as reported (Poliana et al., 2013). The results showed also that sample (G2) pointed that values were close to or above 8 , for all sensory properties, this pointed that most of the panelists "preferre" this samples. Where the values of sample (G1) varied between 5.2 to 7.23 , indicating that most of the panelists "preferre" this product also.

Table 6: Sensory evaluation of hydrolyzed collagen and hydrolyzed made with added orange essence powder, as well as ascorbic acid

\begin{tabular}{cccc}
\hline Parameters & \multicolumn{2}{c}{ Hydrolyzed collagen } & L SD \\
\hline Color & $6.10^{\mathrm{b}} \pm 0.6$ & $8.13^{\mathrm{a}} \pm 0.52$ & 1.273 \\
Odor & $6.40^{\mathrm{b}} \pm 0.4$ & $8.3^{\mathrm{a}} \pm 0.4$ & 0.907 \\
Taste & $5.20^{\mathrm{b}} \pm 0.4$ & $8.235^{\mathrm{a}} \pm 0.4$ & 1.202 \\
Texture & $7.23^{\mathrm{b}} \pm 0.33$ & $8.2^{\mathrm{a}} \pm 0.3$ & 0.715 \\
Overall acceptability & $6.23^{\mathrm{b}} \pm 0.35$ & $8.22^{\mathrm{a}} \pm 0.33$ & 0.771 \\
\hline
\end{tabular}

The values in same a row followed by the same letter are not-significantly different $(\mathrm{P} \leq 0.05)$.

$\mathrm{G} 1=$ Powder of the freeze-dried collagen sample without any additives.

$\mathrm{G} 2=$ Powder of the freeze-dried collagen added to it orange essence powder, as well as ascorbic acid. 
This results confirmed with the results obtained by Masoud, (2017). When compared hydrolyzed collagen with concentrated orange juice and with hydrolyzed collagen as control, where indicated that all samples were accepted, and hydrolyzed collagen with concentrated orange juice was higher than that produce without adding orange juice concentrate in all attributes of sensory evaluation .

\section{Conclusion}

This study concluded that could be use Chicken feet (considered as by-products) as an alternative source cheap and safe (socio-cultural and health concerns) of hydrolyzed collagen for the development of new products, our study used enzymatic hydrolysis method for chicken feet considered by-product to produce hydrolyzed collagen with orange flavor manufacturing to be food supplement for arthritis and roughness of joints. The results indicated that the hydrolyzed collagen that produced in this study was high in the all treatments (concentrate enzyme $0.03,0.04$ and $0.05 \%$ ) of glycine, the proline and hydroxyproline content, as know that proline and hydroxyproline percent were very important for producing glucosamine in the human body in presence of ascorbic acid. The results showed that adding orange essence powder, as well as ascorbic acid during producing of hydrolyzed collagen increased the nutritional value especially vitamin $\mathrm{C}$, where increased from 0 $\mathrm{mg} / 100 \mathrm{~g}$ in hydrolyzed collagen without any additives (G1) to $500 \mathrm{mg} / 100 \mathrm{~g}$ in hydrolyzed collagen with orange essence, as well as ascorbic acid (G2). It was found that color, taste, odor, texture and overall acceptability for hydrolyzed collagen with orange essence, as well as ascorbic acid (G2) were higher than hydrolyzed collagen without any additives (G1).

\section{References}

Aitken, A., J.C. Casey, I.F. Penny, and C.A. Voyle, 1962. Effect of drying temperature in the accelerated freeze drying of pork. J. Sci. of Food Agric., 439-442.

Alves, S. G. T., and S. H. Prudencio-Ferreira, 2002. Propriedades funcionais de material colagenoso de pés de frango. Archivos Latinoamericanos de Nutricion, 52(3), 289-293.

A.O.A.C., 2005. Official methods of analysis of the Association of Official Analytical Chemists, $178^{\text {th }}$ Edn (edited by W. Horwitz Washington, D.C., U.S.A.)

Arauja, I.B.S., K.B. Taliana, S. N. Edilza, and A.A.G. Carlos, 2018. Optimal conditions for obtaining collagen from chicken feet and its characterization. Food Sci. Technol, Campinas, 0101-2061.

Barcelos, M.F.P., E.V.B. Vilas Boas and M.A.C. Lima, 2002. Nutritional aspects of combined sprouts of soybean and corn. Ciência e Agrotecnologia, 26 (4):817-825.

Barimalaa, I.S. and C.O. Okoroji, 2009. Particle size distribution of commercial cowpea (Vigna unguiculata (L) Walp.) Flour and sensory properties of akara. International Journal of Food Engineering, 5(4): 1-5.

Barbosa-Canovas, G.V. E. Ortega-Rivas, P. Juliano, and H. Yan, 2005. Food powders: Physical properties, processing and functionality. Kluwer Academic/Plenum Publishers, New York, ISBN-13: 978-0306478062.

Brandsch, M., 2013. Drug transport via the intestinal peptide transporter PepT1. Curr Opin Pharmacol., 13(6): 881-887.

Bses, 2001a. Laboratory Manual for Australian Sugar Mills, Method 10 (Vol. 2). Indooropily, QLD, Australia: Bureau of Sugar Experiment Stations.

Brookfield Manual, 1998. Brook field Manual Operating Instruction. No. M/98-211-B0104. Brookfield Engineering Laboratories Inc., Middleborough.

Cano-Chauca, M., P.C. Stringheta, A.M. Ramos, and C. Cal-Vidal, (2005).Effect of the carriers on the microstructure of mango powder obtained by spray drying and its functional characterization. Innovative Food Science and Emerging Technologies, (6):420-428.

Costa, D.P.S., P.F. Romanelli and E. Trabuco, 2008. Aproveitamento de vísceras não comestíveis de aves para elaboração de farinha de carne. Ciência e Tecnologia de Alimentos, 28 (3): 746-752.

Eastman, J.E. and C.O. Moore, 1984. Cold water soluble granular starch for gelled food composition. U.S. Patent., 4465702.

Gabriela, M., C. Ciprian, I. Mădălina , A. Luminița, and G. Dana, 2018.Validation of Method for Determining The Isoelectric Point of Protein Solutions. Leather and Footwear Journal, 18(1):5366 . 
Goula, A.M. and K.G. Adamopoulus, 2008. Effect of maltodextrin addition during spray drying of tomato pulp in dehumidified air: II. Powder properties. Drying Journal. 26:726-737.

Hashim, P., M.S.M. Ridzwan and J. Bakar, 2014. Isolation and characterization of collagen from chicken feet. International Journal of Biological, Agricultural, Biosystems. Life Science and Engineering, 8, 231-235.

Hatanaka, T., K. Kawakami, and M. Uraji, 2014. Inhibitory effect of collagen-derived tripeptides on dipeptidylpeptidase-IV activity. J Enzyme Inhib Med Chem., 29(6): 823-828.

Hernandez-Briones, A., M.V.G. Velazquez and J.A. Ramirez, 2009. Effects of adding fish gelatin on Allaska Pollock surimi gels. Food Hydrocolloids, 23: (8) 2446-2449.

Hongdong, S. and L. Bo, 2017. Beneficial Effects of Collagen Hydrolysate: A Review on Recent Developments. Biomed J Sci \& Tech Res., 2(1): 1-4.

Karim, A. A. and R. Bhat, 2009. Fish gelatin: properties, challenges, and prospects as an alternative to mammalian gelatins. Food Hydrocolloids, 23(3): 563-576.

Kramer, R.Z., J. Bella, P.B. Mayville and H.M.B. Brodsky, 1999. Sequence dependent conformational variations of collagen triple-helical structure. Nat. Struct. Biol. 6: 454-457.

Lafarga, T. and M. Hayes, 2014. Bioactive peptides from meat muscle and by-products: generation, functionality and application as functional ingredients. Meat Science, 98(2): 227-239.

Laufenberg, G., B. Kunz, and M. Nystroem, 2003. Transformation of vegetable waste into added products: (A) the upgrading concept; (B) practical implementations. Bioresource Technology, 87(2):167-198.

Lin, Y.K. and D.C. Liu, 2006. Effects of pepsin digestion at different temperatures and times on properties of telopeptide-poor collagen from bird feet. Food Chemistry, 94(4): 621-625.

Masoud, M.R., 2017. Production of Hydrolyzed Bovine Collagen with Orange Juice Concentrate. Egypt. J. Agric. Res., 95 (3):1205-12017.

Milliporo Cooperative,1987. Liquid chromatographic analysis of amino acids in food using a modification of the PICO- TAG method, U.S.A

Morimura, S., H. Nagata, Y. Uemura, A. Fahmi, T. Shigematsu and K. Kida, 2002. Development of an effective process for utilization of collagen from livestock and fish waste. Proc. Biochem., 37, $1403-1412$.

Ohara, H., S. Ichikawa, H. Matsumoto, M. Akiyama, and N. Fujimoto, 2010. Collagen-derived dipeptide, proline-hydroxyproline, stimulates cell proliferation and hyaluronic acid synthesis in cultured human dermal fibroblasts. J Dermatol., 37(4): 330-338.

Oesser, S., M. Adam, W. Babel and J. Seifert, 1999. Oral administration of 14C labeled gelatin hydrolysate leads to an accumulation of radioactivity in cartilage of mice (C57/BL). J Nutr., 129(10):1891-1895.

Orrico Junior, M.A.P., A.C.A. Orrico and J. Lucas Junior, 2010a .Avaliação De Parâmetros Da Biodigestão Anaeróbia De Dejetos De Suínos Alimentados Com Dietas À Base De Milho E Sorgo. Engenharia Agrícola, Jaboticabal., 30( 4): 600-607.

Orrico Junior, M.A.P., A.C.A.E. Orrico, J. Lucas Junior, 2010b. Biodigestão Anaeróbia Dos Resíduos Da Produção Avícola: Cama De Frangos E. Carcaças. Engenharia Agrícola, Jaboticabal., 30(3):546-554.

Polian, F.A., 2012. Collagen extraction from chicken feet for jelly production. Acta Scientiarum Technology Maringá, 34(3):345-351.

Poliana, F. D., A.C. Felip and C. S. José Carlos, 2013. Production of a product similar to gelatin from chicken feet collagen. Eng. Agríc., Jaboticabal.,33(6):1289-1300

Rodrigues, J.A.G., A.L.G. Quinderé, I.N.L. Queiroz, C.O. Coura, G.S. Araújo and N.M.B. Benevides, 2011. Purification, physical and chemical characterization, and anticoagulant activity of glycosaminoglycans isolated from the skin of Nile tilapia (Oreochromis niloticus). Acta Scientiarum Technology, 33(3): 233-241.

SAS, 1996. SAS/STAT1 User's Guide, Version 8, SAS Institute Inc, Cary, NC.

Sanchez-Alonso, I., E.A. Jimenez, Sura F. and Borderias, A. J., 2007. Antioxidant protection of white grapa pomace on restructured fish products during frozen storage. Food Sci. and Technolo., 41(1): $1-9$.

Simões, G. S., E.T.F. Silveira, S.R. Oliveira, E. Poleze, J.R. D.Allison, E.I. Ida, and M. Shimokomaki, 2014. Optimum conditions for extracting collagen from the tunica albuginea of immunologically 
castrated pig testes and the functional properties of the isolated collagen. Meat Science, 96(4), 1460-1468. http://dx.doi.org/10.1016/j.meatsci.2013.10.038. PMid:24412738.

Song, H., M. Meng, X. Cheng, B. Li, and C. Wang, 2017. The effect of collagen hydrolysates from silver carp (Hypophthalmichthys molitrix) skin on UV-induced photo aging in mice: molecular weight affects skin repair. Food Funct. 8(4): 1538-1546.

Suderman, D. R., J. Wiker and F.E. Cunningham, 1981. Factors affecting adhesion of coating to poultry skin. effects of various protein and gum sources in the coating composition. Food Sci., 46: 1010-1011.

Wang, L., Q. Wang, Q. Liang, Y. He and Z. Wang et al., 2015. Determination of bioavailability and identification of collagen peptide in blood after oral ingestion of gelatin. J Sci Food Agric., 95(13): 2712-2717.

Wei ,W., L. Zhonglei, L. Junzhong, W. Yuejun, L. Shanhong, and S. Mi, 2013. Comparison between Thermal Hydrolysis and Enzymatic Proteolysis Processes for the Preparation of Tilapia Skin Collagen Hydrolysates. Czech J. Food Sci., 31(1): 1-4.

Yang, J.I., W.S. Liang, C.J. Chow, and K.J. Siebert, 2009.Process for the production of tilapia retorted skin gelatin hydrolysates with optimized antioxidative properties. Process Biochemistry, 44: $1152-1157$.

Yazaki, M., Y. Ito, M. Yamada, S. Goulas and S. Teramoto et al., 2017. Oral Ingestion of Collagen Hydrolysate Leads to the Transportation of Highly Concentrated Gly-Pro-Hyp and Its Hydrolyzed Form of Pro-Hyp into the Bloodstream and Skin. J Agric Food Chem., 65: 23152322. 